\title{
Identitas Nasional, Pemahaman Pancasila dan Relasi Interpersonal Anggota DPRD Sumatera Selatan
}

\author{
${ }^{1}$ Sarah Afifah, ${ }^{2}$ Kwartarini Wahyu Yuniarti, ${ }^{3}$ Catur Widiatmoko \\ ${ }^{1}$ Fakultas Psikologi, Universitas Islam Negeri Raden Fatah, \\ ${ }^{2}$ Fakultas Psikologi, Universitas Gadjah Mada, \\ ${ }^{3}$ Fakultas Psikologi, Universitas Islam Negeri Raden Fatah,
}

${ }^{1}$ sarah.afifah@ugm.ac.id, ${ }^{2}$ kwartarini_psy@ugm. Ac.id, ${ }^{3}$ Catur19widiat@gmail.com

\begin{abstract}
Abstrak
Penelitian ini bertujuan untuk mengetahui pengaruh identitas nasional dan pemahaman Pancasila terhadap relasi interpersonal anggota DPRD Sumsel. Relasi interpersonal adalah hubungan antar individu untuk performa kerja. Salah satu upaya untuk meningkatkan performa kerja adalah dengan meningkatkan relasi interpersonal. Faktor yang mempengaruhi relasi interpersonal dari aspek individu adalah identitas nasional dan pemahaman Pancasila. Identitas nasional adalah identifikasi individu kepada negaranya sedangkan pemahaman Pancasila adalah kemampuan anggota DPRD dalam memahami ideologi Pancasila. Subjek penelitian berjumlah 58 orang anggota DPRD Sumatera Selatan periode 2014-2019 dari berbagai fraksi. Penelitian ini merupakan penelitian kuantitatif dengan metode survei. Instrumen penelitian menggunakan skala yakni skala identitas nasional, pemahaman Pancasila dan relasi interpersonal. Adapun hasil penelitian menggunakan analisis regresi berganda menunjukan bahwa identitas nasional dan pemahaman Pancasila secara bersama-sama berpengaruh pada relasi interpersonal $(\mathrm{p}=0.001)$. Identitas nasional memiliki kontribusi yang lebih besar dalam memengaruhi relasi interpersonal dibanding pemahaman Pancasila.
\end{abstract}

Kata kunci: relasi interpersonal; identitas nasional, pemahaman pancasila

\begin{abstract}
This research was aimed to determine the effect of national identity and Understanding of Pancasila toward the interpersonal relationship of DPRD Sumsel (South Sumatera Regional House of Representative) members. The aforementioned interpersonal relationship is an inter-individual relation aimed for the work performance. One of the way to increase the productivity is by increasing the interpersonal relationship. Factors affecting the interpersonal relationship from the individual aspects are the national identity and the Understanding of Pancasila. National identity is the individuals' identification toward their country while the understanding of Pancasila is the ability of the DPRD members in understanding the ideology of Pancasila. The research subjects consisted of 58 South Sumatera DPRD members for the period of 2014-2019 from several fractions. This research is a quantitative research using survey method. The research instruments were scales consist of national identity, understanding of Pancasila, and interpersonal relationship scale. The result of this research using multiple analysis showed that the national identity and understanding of Pancasila simultaneously affect the interpersonal relationship. The national identity has bigger contribution in affecting the interpersonal relationship compared to the understanding of Pancasila. Keywords: interpersonal relation, national identity, understanding Pancasila.
\end{abstract}

Keywords: interpersonal relation; national identity; understanding Pancasila

\section{PENDAHULUAN}

Indonesia yang menganut sistem demokrasi sebagai sistem politiknya mengharuskan pemerintah dalam hal ini anggota dewan untuk membangun relasi atau hubungan antar anggota dalam berbagai bentuk baik kerjasama maupun persaingan. Menurut Balliet, Tybur, Wu, 
Antonellis, dan Lange (2016) untuk mempertahankan sistem demokrasi agar berjalan dengan baik setiap anggota bekerjasama melakukan negosiasi dengan anggota lain, membuat konsensus dan membuat keputusan. Penelitian yang dilakukan oleh Alfaruqy (2016) menemukan bentuk hubungan atau relasi interpersonal yang terjalin antar anggota dewan adalah hubungan kooperatif, kompetitif dan pasif. Relasi yang dapat menunjang produktivitas berdasarkan penelitian Suhanda (2002) adalah dalam bentuk kerjasama atau kooperatif.

Wawancara awal kepada anggota DPRD Sumsel dilakukan di Yogyakarta pada tanggal 12 Oktober 2017. Wawancara awal menunjukkan bahwa anggota DPRD masih mementingkan kepentingan pribadi atau kelompoknya dalam membuat keputusan atau kebijakan. Perilaku tidak dapat bekerja sama dalam menjalankan tugas juga masih ditampilkan beberapa anggota DPRD Sumsel misalnya disebabkan karena pengetahuan anggota DPRD yang kurang mengenai topik dan tidak ada kemauan untuk mencari informasi, malas dan tidak hadir saat rapat adalah contoh perilaku anggota DPRD yang kurang dapat bekerja sama. Rasa tidak percaya dan curiga juga masih terjadi ketika anggota DPRD menjalankan tugasnya. Rasa curiga terjadi terhadap implementasi keputusan rapat yang tidak sesuai dengan hasil keputusan itu sendiri dan hal ini menimbulkan kecurigaan.

Relasi interpersonal ini berdampak pada produktivitas kerja. Produktivitas dan hasil kerja yang adekuat merupakan hasil dari relasi interpersonal yang baik dalam ranah pekerjaan (Bennis, Schein, Berlew, \& Steele, 1979). Hasil kerja anggota DPRD Sumsel dapat dilihat salah satunya dari produk hukum yang dibuat yakni peraturan daerah inisiatif. Berdasarkan data DPRD Sumsel usulan Perda. Perda tahun 2017 usulan Perda yang diterima hanya sebanyak 7 Perda (Alwi, 2017). Produktivitas anggota DPRD apabila dilihat dari Perda inisiatif yang disahkan dan dibahas tiap tahunnya sejak tahun 2017 dirasa belum sepenuhnya efektif.

Fenomena mengenai relasi interpersonal di DPRD Sumsel tersebut salah satunya terjadi karena anggota DPRD berasal dari latar belakang dan memiliki pengalaman-pengalaman berbeda yang sangat berpengaruh ketika mereka menjalankan tugas. Ellemers dan Haslam (2012) menjelaskan bahwa dalam berinteraksi atau berhubungan dengan orang lain setiap individu mengedepankan identitas sosial atau identitas kelompoknya dibanding identitas personal. Konflik dapat terjadi diakibatkan kategorisasi ini, konflik tersebut diakibatkan menguatnya identitas-identitas kelompok yang berujung pada penundukan satu sama lain (Faturochman, 2008). Melluci (dalam Fominaya, 2010) menawarkan identitas kolektif sebagai sebagai salah satu konsep yang menghasilkan dan mempertahankan kohesivitas dalam gerakan sosial atau kelompok. Usaha ini yakni dengan cara individu mengidentifikasikan dirinya kepada identitas kelompok yang lebih umum tanpa mengubah identitas yang ada secara total, identitas tersebut dapat mewadahi semua kelompok (Faturochman, 2008). Adapun identitas yang lebih umum tertuang dalam identitas nasional sebagai identitas kolektif bangsa Indonesia dalam hal ini anggota dewan.

Di lain pihak menurut Yuniarti (2015) pengaruh dari globalisasi membuat identitas nasional bangsa Indonesia menjadi terganggu dan bermasalah. Pengaruh globalisasi, pendidikan yang tidak mengajarkan pentingnya identitas nasional dapat menjadi penyebab masyarakat tumbuh dengan tidak mengedepankan identitas mereka sebagai orang Indonesia (Yuniarti, 2015). Identitas nasional yang seharusnya dapat mewadahi dan menjadi pemersatu dalam pemerintahan berada dalam keadaan rentan.

Mengenai hubungan identitas nasional terhadap relasi interpersonal sudah pernah dilakukan penelitian sebelumnya. Buchan, Brewer, Grimalda, Wilson, dan Foddy (2016) menemukan identifikasi kepada yang lebih kolektif atau umum meningkatkan relasi kooperatif. Penelitian yang dilakukan Borland (2014) terhadap kelompok yang berkonflik menunjukkan bahwa narasi tentang identitas kolektif dapat meningkatkan hubungan mereka. 
Hal lain yang dapat berpengaruh pada relasi antar anggota DPRD adalah pemahaman anggota DPRD terhadap ideologi bangsa kita yakni Pancasila. Namun masih banyak masyarakat tidak memahami nilai-nilai Pancasila dan melaksanakan dalam kehidupan bernegara. Hal ini sesuai dengan hasil survei Badan Pusat Statistik tahun 2011 mengenai kehidupan bernegara ini juga menunjukan sebanyak $89,4 \%$ masyarakat dari berbagai tingkat hingga pemerintah setuju bahwa penyebab konflik bangsa Indonesia belakangan ini adalah dikarenakan kurangnya pemahaman dan pengamalan nilai-nilai Pancasila dalam kehidupan sehari-hari.

Menurut Natsir (2010) permasalahan elit politik yang terjadi belakangan ini diantaranya adalah rendahnya kesadaran pemahaman, penghayatan dan pemalan Pancasila. Penelitian mengenai hubungan ideologi terhadap relasi interpersonal misalnya dilakukan oleh Sosis dan Ruffle (2006) menunjukan bahwa orang-orang Israel yang memilki ideologi religius lebih kooperatif daripada individu dengan ideologi sekuler. Penelitian yang dilakukan oleh Balliet et al.,(2016) menunjukan bahwa ideologi politik berhubungan dengan relasi kooperatif. Individu dengan ideologi liberal lebih menunjukan perilaku kooperatif dibanding individu dengan ideologi konservatif. Dari penelitian tersebut dapat peneliti simpulkan bahwa setiap ideologi memiliki pengaruh yang berbeda-beda terhadap hubungan interpersonal.

Berdasarkan paparan di atas peneliti tertarik untuk meneliti hubungan ketiganya yakni identitas nasional, pemahaman terhadap Pancasila dan relasi interpersonal anggota dewan. Hal ini penting karena dapat menjadi masukan untuk pemerintah dalam rangka pengembangan relasi antar anggota DPRD dengan memperhatikan identitas nasional dan pemahaman terhadap ideologi bangsa Indonesia yaitu Pancasila.

\section{METODE}

Variabel dalam penelitian ini adalah relasi interpersonal sebagai variabel dependen atau terikat dan variabel identitas nasional dan Pemahaman Pancasila sebagai variabel independen atau bebas. Definisi relasi interpersonal adalah relasi yang terjalin antar anggota DPRD untuk performa tugas. Relasi interpersonal didalamnya terdapat dua dimensi yakni orientasi pada rasa percaya dan orientasi pencapaian tujuan bersama (Suhanda, 2002).. Definisi identitas nasional adalah Identifikasi individu terhadap identitas nasionalnya yakni Indonesia. Terdiri dari elemen self categorization, evaluation, importance, attachmentand sense of interdependence dan behavior involvement Ashmore, et al., (2004). Pemahaman Pancasila disusun berdasarkan teori Pancasila dari Kaelan (2016).

Penelitian menggunakan jenis teknik sampling non probability sampling yakni sampling jenuh. Adapun kriteria subjek penelitian pada penelitian ini adalah merupakan anggota DPRD Sumsel pada periode jabatan 2014-2019 dan masih aktif menjabat. Berasal dari partai, daerah pemilihan, fraksi, komisi dan memiliki posisi jabatan yang berbeda-beda. Aktif menjalin hubungan dengan sesama anggota DPRD Sumsel. Bersedia untuk disertakan dalam penelitian ini.

Penelitian ini merupakan penelitian kuantitatif dengan metode survei. Adapun instrumen yang digunakan dalam penelitianini adalah berupa skala. Skala relasi interpersonal peneliti modifikasi berdasarkan skala yang disusun oleh Sumantri pada tahun 1997 dan sebelumnya telah dimodifikasi oleh Suhanda (2002). Skala identitas nasional peneliti susun berdasarkan teori elemen identitas kolektif menurut teori Ashmore, et al., (2004). Peneliti menyusun skala pemahaman Pancasila berdasarkan teori pemahaman Bloom (Eysenck \& Keane, 2001) yakni mengingat, menafsirkan, mencontohkan dan membedakan. Adapun indikator pemahaman Pancasila berdasarkan teori Kaelan (2016) dan diskusi dengan ahli filsafat menambahkan 
pemahaman akan kesatuan Pancasila sebagai salah satu indiaktor.

Validitas isi skala dilakukan dengan menghitung Aiken's $V$ dan reliabilitas menggunakan Cronbach $\alpha$. Skala relasi interpersonal nilai Aiken's $V$ berkisar antara 0,535 - 0,797 tidak ada aitem yang gugur. Reliabilitas skala relasi interpersonal dengan nilai Cronbach $\alpha 0,823$ menunjukan skala ini reliabel. Validitas isi identitas nasional dengan Aiken's $V$ berkisar antara 0,6 - 0,797. Nilai Cronbach $\alpha$ skala identitas nasional 0,872 dapat dikatakan bahwa skala identitas nasional ini reliabel. Validitas isi pemahaman Pancasila dengan nilai Aiken's V 0,5830,75 menunjukan skala pemahaman Pancasila valid tidak ada aitem yang gugur.

\section{HASIL}

Subjek penelitian berjumlah 58 orang, peneliti tidak bisa mengambil seluruh populasi dikarenakan ada beberapa responden yang menolak untuk berkontribusi. Berdasarkan jenis kelamin subjek dalam penelitian ini didominasi oleh laki-laki yakni sebanyak 48 orang dan perempuan sebanyak 10 orang. Berdasarkan usia mayoritas subjek berusia antara 41-50 tahun yakni sebanyak 27 orang. Sedangkan berdasarkan tingkat pendidikan subjek penelitian mayoritas telah menempuh jenjang pendidikan S2 yakni sebanyak 28 orang. Gambaran subjek berdasarkan komisi di DPRD Sumsel yakni subjek mayoritas berasal dari komisi V. Gambaran berdasarkan fraksi dimana anggota DPRD berasal yakni mayoritas anggota DPRD yang menjadi subjek penelitian ini berasal dari fraksi Golkar yakni sebanyak 11 orang.

Tabel 1.

Demografi Subjek Penelitian

\begin{tabular}{lll}
\hline Jenis Kelamin & Laki-Laki (48 orang) & Perempuan (10 orang) \\
\hline Usia & $41-50$ tahun (27 orang) & 51-60 (21 orang) \\
Pendidikan & S2 (28 orang) & S1 (26 Orang) \\
Komisi & Komisi V (14 Orang) & Komisi I (11 Orang) \\
Fraksi & Golkar (11 orang) & PDIP (10 Orang) \\
\hline
\end{tabular}

Berdasarkan tabel 2 dapat diketahui nilai mean dependen variabel relasi interpersonal dari data empirik yakni 109, nilai ini lebih besar dari mean data hipotetik yakni 102,5 ini menunjukan bahwa subjek penelitian memiliki relasi interpersonal yang lebih tinggi dari seharusnya. Nilai mean independen variable identitas nasional dari data empirik yakni 127,8 lebih besar dari mean hipotetik yakni 95 menunjukan identitas nasional subjek penelitian lebih besar dari yang seharusnya. Nilai mean independen variabel pemahaman Pancasila dari data empirik 27,5 lebih besar dari mean hipotetik yakni 19, hal ini menunjukkan pemahaman Pancasila subjek penelitian lebih tinggi dari yang seharusnya.

Tabel 2.

Statistik Deskriptif

\begin{tabular}{lccccccccccc}
\hline \multirow{2}{*}{ Variabel } & \multicolumn{4}{c}{ Hipotetik } & \multicolumn{5}{c}{ Empirik } \\
\cline { 2 - 12 } & Range & Min & Max & X & SD & Range & Min & Max & X & SD \\
\hline Relasi interpersonal & 20,5 & 41 & 164 & 102,5 & 27,3 & 42 & 101 & 143 & 109 & 9,2 \\
Identitas nasional & 114 & 38 & 152 & 95 & 19 & 37 & 114 & 151 & 127,81 & 9,2 \\
Pemahaman Pancasila & 38 & 0 & 38 & 19 & 6 & 14 & 20 & 34 & 27,5 & 3,8 \\
\hline
\end{tabular}

Pada table 3 relasi interpersonal anggota DPRD rata-rata berada pada kategori sedang yakni 33 orang dan tinggi sebanyak 25 orang. Pada skala identitas nasional anggota DPRD berada 
pada kategori tinggi paling banyak yakni sebanyak 55 orang $(94,8 \%)$ dan ada kategori sedang sebanyak 3 orang $(5,2 \%)$. Pada skala pemahaman Pancasila skor individu terbanyak pada kategori tinggi yakni sebanyak 38 orang $(65,5 \%)$ dan pada kategori sedang sebanyak 20 orang $(34,5 \%)$.

Tabel 3.

Deskriptif kategori variabel penelitian

\begin{tabular}{lcccccc}
\hline \multirow{2}{*}{ Variabel } & \multicolumn{2}{c}{ Rendah } & \multicolumn{2}{c}{ Sedang } & \multicolumn{2}{c}{ Tinggi } \\
\cline { 2 - 7 } & Jumlah & Persen(\%) & Jumlah & Persen(\%) & Jumlah & Persen(\%) \\
\hline Relasi Interpersonal & 0 & 0 & 33 & 56,8 & 25 & 43,1 \\
Identitas nasional & 0 & 0 & 3 & 5,2 & 55 & 94,8 \\
Pemahaman Pancasila & 0 & 0 & 20 & 34,5 & 38 & 65,5 \\
\hline
\end{tabular}

Uji normalitas penelitian menggunakan normalitas residual dengan Kolmogorov Smirnov. Nilai residual Kolmogorov Smirnov 0,526 dengan nilai signifikansi 0,945 (p>0,05) dengan demikian data residual penelitian dapat dikatakan berdistribusi normal. Berdasarkan ketentuan nilai $F$-Deviation from linearity model hubungan antara variabel dikatakan linear apabila nilai signifikansi F-Deviation from linearity lebih dari 0,05 ( $\mathrm{p}>0,05)$. Sehingga Dengan melihat tabel 3 diketahui bahwa model identitas nasional dan relasi interpersonal memiliki nilai signifikansi $0,937(\mathrm{p}>0,05)$ dengan $\mathrm{F}=0,535$. Model pemahaman Pancasila dan relasi interpersonal nilai signifikansi $0,595(\mathrm{p}>0,05)$ dengan $\mathrm{F}=0,863$. Dapat dikatakan kedua model tersebut memiliki hubungan yang linear.

Tabel 4.

Uji Lineritas $F$ deviation from linearity

\begin{tabular}{llll}
\hline Variabel & F & Sig. & Keterangan \\
\hline Relasi * Identitas & 0,535 & 0,937 & Linear \\
Relasi*Pemahaman pancasila & 0,863 & 0,595 & Linear \\
\hline
\end{tabular}

Penelitian dengan model analisis regresi seharusnya tidak terjadi korelasi antara varibel bebas atau disebut dengan multikolinearitas. Variabel dapat dikatakan tidak multikolinearitas apabila nilai tolerance lebih besar dari 0,1 dan VIF lebih kecil dari 10. Berdasarkan analisis identitas nasional memiliki nilai tolerance 0,635 dan nilai VIF 1,574. Pada pemahaman Pancasila memiliki nilai tolerance 0,635 dan VIF 1,574. Dari nilai tersebut menunjukkan bahwa nilai tolerance kedua model lebih besar dari 0,1 dan VIF lebih kecil dari 10, dapat dikatakan tidak terdapat multikolinearitas pada kedua model ini.

Tabel 5.

Uji hipotesis

\begin{tabular}{cccc}
\hline Model & $\mathbf{R}^{\mathbf{2}}$ & $\mathbf{F}$ & Sig \\
\hline Identitas nasional, pemahaman Pancasila dan relasi interpersonal & 0,214 & 7,490 & $0,001 * *$ \\
\hline Keterangan : ${ }^{* *} \mathrm{P}<0,01 * \mathrm{P}<0,05$ & & &
\end{tabular}

Berdasarkan tabel 5 nilai signifikansi $0,001(\mathrm{~F}=7,490 ; \mathrm{P}<0,01)$ dengan $R^{2} 0,185$, hal ini menunjukan bahwa terdapat pengaruh yang signifikan secara bersama-sama identitas nasional dan pemahaman Pancasila terhadap relasi interpersonal. Berdasarkan nilai $R^{2} \quad 0,214$ menandakan bahwa variasi dependen variabel relasi interpersonal dapat dijelaskan oleh variasi variabel independen identitas nasional dan Pemahaman Pancasila sebanyak 21,4\%. 
Tabel 6.

Sumbangan efektif variabel independen

\begin{tabular}{lcccc}
\hline \multicolumn{1}{c}{ Variabel } & $\boldsymbol{\beta}$ & Cross Product & Regresi & Sumbangan Efektif \\
\hline Identitas Nasional & 0,472 & 2320,2 & \multirow{2}{*}{1097,8} & $18,5 \%$ \\
Pemahaman Pancasila & 0,003 & 590,5 & & $2,9 \%$ \\
\hline Jumlah & & & & $21,4 \%$ \\
\hline
\end{tabular}

Adapun sumbangan efektif masing-masing variabel independen yakni identitas nasional dan pemahaman Pancasila terhadap dependen variabel relasi interpersonal digambarkan pada tabel 6. Besaran sumbangan efektif total adalah $21,4 \%$, dimana sebanyak $18,4 \%$ berasal dari identitas nasional dan pemahaman Pancasila sebesar 2,9\%. Apabila dilakukan analisis secara terpisah, pengaruh masing-masing variabel independen yakni identitas nasional dan pemahaman Pancasila terhadap dependen variabel relasi interpersonal dapat dilihat pada tabel 7 dibawah ini:

Tabel 7.

Uji Hipotesis masing-masing variabel independen

\begin{tabular}{cccc}
\hline \multicolumn{1}{c}{ Variabel } & $\boldsymbol{\beta}$ & $\mathbf{T}$ & Sig. \\
\hline Identitas Nasional & 0,472 & 3,080 & $0,00^{* *}$ \\
Pemahaman Pancasila & 0,003 & 0,008 & $0,033^{*}$ \\
\hline Keterangan : ** $\mathrm{P}<0,01 * \mathrm{P}<0,05$ & &
\end{tabular}

Dari tabel diatas ditemukan bahwa variabel identitas nasional dan pemahaman Pancasila keduanya mempengaruhi relasi interpersonal. Identitas nasional memiliki pengaruh yang signifikan terhadap relasi interpersonal dengan nilai signifikansi sebesar $0,00(t=3,08 ; P<0,01$ ). Model pemahaman Pancasila terhadap relasi interpersonal memiliki signfikansi 0,033 $(\mathrm{t}=0,008 ; \mathrm{p}<0,05)$ menunjukan bahwa pengaruh pemahaman Pancasila signifikan terhadap relasi interpersonal.

\section{DISKUSI}

Terdapat beberapa temuan dari penelitian ini. Pertama, variabel independen identitas nasional dan pemahaman terhadap Pancasila bersama-sama memberikan pengaruh yang signifikan kepada variabel dependen relasi interpersonal anggota DPRD Sumsel. Kedua, apabila dianalisis terpisah baik identitas nasional dan pemahaman Pancasila memiliki pengaruh yang signifikan terhadap variabel dependen relasi interpersonal. Ketiga, relasi interpersonal yang terjalin anggota DPRD Sumsel mayoritas berada pada kategori sedang, identitas nasional berada pada kategori tinggi dan pemahaman Pancasila berada pada kategori sedang. Keempat, identitas nasional memiliki kontribusi lebih besar dibanding pemahaman Pancasila terhadap pengaruhnya kepada relasi interpersonal.

Penelitian ini menemukan bahwa terdapat pengaruh yang signifikan secara bersama-sama atau secara serentak identitas nasional dan pemahaman Pancasila terhadap relasi Interpersonal dimana identitas nasional memberikan kontribusi efektif terbesar sebanyak dibandingkan pemahaman Pancasila. Temuan mengenai pengaruh identitas nasional dan relasi interpersonal ini menegaskan hasil penelitian sebelumnya yang dilakukan oleh Buchan et al.,(2016) bahwa individu yang mengidentifikasikan pada identitas yang lebih umum atau kolektif seperti identitas nasional memiliki relasi interpersonal yang lebih baik. Identitas yang lebih kolektif dalam hal ini adalah identitas nasional seperti temuan Sameela (2012). 
Identitas nasional mempengaruhi relasi interpersonal dengan jalan kesamaan identitas dan kesamaan tujuan. Faktor kesamaan ini mempengaruhi relasi interpersonal anggota DPRD Sumsel. Apabila anggota DPRD lebih melihat kesamaan dibanding perbedaan yakni sama-sama bangsa Indonesia dan memiliki kesamaan tujuan mensejahterakan rakyat Indonesia maka relasi yang ditampilkan menjadi lebih baik. Faktor kesamaan identitas atau penggunaan identitas yang lebih umum atau identitas nasional mempengaruhi orientasi tujuan bersama anggota DPRD. Sebelum anggota DPRD berinteraksi dengan anggota lain mereka melakukan seleksi. Seleksi ini berdasarkan kategorisasi yang berasal dari identitas anggota lain tersebut, baik identitas yang bersifat personal maupun sosial. Anggota DPRD lebih mau berhubungan dan bekerja sama dengan individu yang memiliki kesamaan dengan dirinya.

Pemahaman Pancasila mempengaruhi relasi interpersonal melalui jalan mengarahkan kepada kesadaran anggota DPRD mengenai Pancasila sebagai orientasi kehidupan konstitusional. Pelaksanaan dan pemahaman Pancasila bagi penyelenggaraan negara merupakan suatu orientasi kehidupan konstitusional (Suseno, 2011). Ada beberapa unsur penting dalam kedudukan Pancasila sebagai orientasi kehidupan konstitusional di antaranya kesediaan untuk saling menghargai dalam kekhasan masing-masing, adanya kesepakatan bersama-sama membangun negara Indonesia dan pluralisme (Suseno, 2011). Anggota DPRD ketika memiliki pemahaman pada Pancasila maka akan memiliki kesadaran dan kesediaan untuk saling menghargai perbedaan, saling menghormati dan sepakat pada tujuan bersama, ini merupakan ciri relasi interpersonal yang baik.

Adapun proses psikologis yang terjadi sehingga anggota DPRD menampilkan relasi interpersonal yang baik atau mau bekerja sama apabila memiliki identitas nasional yang tinggi adalah teori interdependensi sosial dari Tibaut, Kelly dan Homans (2012). Teori ini adalah salah satu pandangan teori pertukaran sosial mengenai saling ketergantungan antara dua individu yang berhubungan. Positive interdependence dimana pencapaian tujuan individu berhubungan positif dengan pencapaian tujuan individu lain sehingga aksi yang diambil adalah aksi yang efektif atau meningkatkan pencapaian tujuan bersama. Negative interdependence dimana pencapaian tujuan individu berhubungan negatif dengan pencapaian tujuan individu lain aksi yang diambil adalah perilaku ceroboh dimana perilaku individu menghambat pencapaian tujuan individu lain (Deutsch, 1983).

Apabila anggota DPRD mengidentifikasikan kepada bangsa dan negara, mereka akan mengadaptasi nilai-nilai dan memiliki tujuan yang sama dan memandang bahwa perilaku anggota DPRD meningkatkan pencapaian tujuan bersama. Interdendensi yang terjadi adalah positif dan perilaku yang ditampilkan adalah relasi interpersonal yang baik yakni mau bekerja sama, saling percaya dan saling menghormati. Sedangkan anggota DPRD yang memiliki identitas nasional yang rendah akan memiliki tujuan dan nilai yang berbeda dengan bangsanya dan menganggap bahwa perilaku anggota DPRD lain menghalangi atau menghambat pencapain tujuan bersama. Interdependensi yang terjadi adalah negatif dan aksi yang diambil adalah aksi ceroboh atau relasi interpersonal yang kurang baik ditandai dengan lebih mementingkan tujuan pribadi, kurang dapat bekerja sama, saling curiga dan tidak percaya dengan anggota lain.

Menurut teori interdependensi sosial proses psikologis yang terjadi antar anggota yang saling tergantung atau interdependen hingga sampai pada relasi yang terjalin adalah substitutability, inducibility dan cathexis. Ketika identitas nasional anggota DPRD tinggi maka memengaruhi substitutability anggota DPRD tersebut, anggota DPRD menjadi mau untuk saling membantu atau mau untuk bekerja sama dengan anggota DPRD lain dikarenakan mempersepsikan bahwa anggota DPRD lain adalah bagian dari kelompoknya sebagai bangsa Indonesia, memiliki tujuan yang sama dengan dirinya dan menganggap anggota lain memberikan kontribusi yang positif untuk kemajuan bersama. Setelah anggota DPRD memiliki 
substitutability yang positif atau bersedia untuk saling membantu, anggota DPRD melakukan cathexis atau penilaian positif kepada anggota DPRD lainnya. Penilaian positif kepada anggota DPRD lainnya memengaruhi rasa percaya dan rasa hormat mereka sehingga selain siap untuk menampilkan perilaku untuk pencapaian tujuan bersama terjadi hubungan atau relasi interpersonal yang dilandasi rasa saling percaya. Tahap terakhir adalah inducibility dimana anggota DPRD telah siap untuk saling dipengaruhi atau memberikan pengaruh positif kepada anggota DPRD lain dalam upaya pencapaian tugas bersama. Ketika anggota DPRD mengidentifikasikan diri sebagai bangsa Indonesia berdasarkan teori identitas sosial Turner dan Reynold (2012) seharusnya mereka juga menginternalisasikan norma dan nilai-nilai yang ada pada kelompoknya, disinilah pemahaman terhadap Pancasila memberikan pengaruh kepada relasi interpersonal anggota DPRD Sumsel. Ketika anggota DPRD memiliki identitas yang kuat sebagai bagian dari bangsa Indonesia anggota DPRD juga menginternaslisasikan norma dan nilai-nilai yang ada pada identitasnya sebagai bangsa Indonesia. Norma dan nilai-nilai yang baik bangsa Indonesia ada pada Pancasila.

Sikap dan nilai-nilai anggota DPRD dalam berbangsa dan bernegara tidak bisa lepas dari Pancasila. Pancasila dipergunakan untuk mengatur pemerintahan negara atau Pancasila digunakan sebagai dasar penyelenggaraan negara (Kaelan, 2016).

Sebelum pada tahap implementasi atau penerapan Pancasila dalam bernegara anggota DPRD memahami mengenai Pancasila itu sendiri agar perilaku dalam bernegara tidak melenceng dari Pancasila. Pemahaman anggota DPRD Sumsel berada pada kategori sedang. Ini berarti anggota DPRD telah memiliki pemahaman yang cukup terhadap Pancasila baik pengertian, kedudukan dan fungsi Pancasila, pemahaman nilai-nilai dasar, kesatuan Pancasila dan implementasi dalam pemerintahan. Sebagai anggota DPRD mereka memiliki pengatahuan yang cukup mengenai bagaimana seharusnya menjalankan tugas dan kewajibanya sesuai dan tidak melenceng dari Pancasila.

Identitas nasional memiliki kontribusi lebih banyak dibandingkan pemahaman Pancasila terhadap pengaruhnya pada relasi interpersonal. Identitas memberikan kontribusi pengaruh yang lebih banyak dikarenakan identitas nasional berada pada level yang lebih dalam, Dibandingkan pemahaman Pancasila yang hanya pada level kognitif saja, identitas nasional memiliki kontribusi yang lebih besar bagi anggota DPRD dalam menampilkan relasi interpersonal yang baik.

Identitas nasional anggota DPRD Sumsel berada pada kategori tinggi ini berarti identifikasi anggota DPRD tinggi kepada negaranya yakni sebagai bangsa Indonesia, adanya evaluasi atau penilaian yang positif kepada negaranya, rasa kepemilikan atau keterikatan emosional yang kuat serta menampilkan perilaku sesuai dengan norma-norma di Indonesia. Pemahaman Pancasila anggota DPRD berada pada kategori sedang ini berarti anggota DPRD cukup memahami pengertian, fungsi, kedudukan, dan implementasi Pancasila dalam kehidupan bernegara. Relasi interpersonal anggota DPRD Sumsel berada pada kategori sedang ini berarti anggota DPRD Sumsel menampilkan perilaku yang berorientasi pada tujuan bersama dan pada rasa percaya yang cukup, walaupun masih ada rasa curiga dan kurang percaya di antara anggota DPRD Sumsel.

\section{KESIMPULAN}

Pengaruh identitas nasional dan pemahaman Pancasila secara bersama-sama terhadap relasi interpersonal anggota DPRD Sumatera Selatan. Hasil uji analisis secara terpisah menunjukkan identitas nasional berpengaruh terhadap relasi interpersonal. Begitu pula dengan pemahaman Pancasila menjadi prediktor munculnya perilaku relasi interpersonal. Identitas nasional lebih 
berperan penting dalam memunculkan relasi interpersonal dibandingkan pemahaman Pancasila. Hal ini dikarenakan aspek identitas nasional yakni katagorisasi diri, evaluasi, keterikatan emosional, kepentingan dan menampilkan perilaku yang sesuai dengan ciri negaranya memiliki level yang lebih dalam, dibandingkan pemahaman Pancasila yang hanya pada level pemahaman. Dengan menidentifikasikan diri kepada Negaranya anggota DPRD berprilaku dan berhubungan dengan anggota lainnya mengedepankan kepentingan Negara di banding kepentingan kelompoknya dan mengedepankan persatuan bangsa. Pemahaman Pancasila memberikan pengaruh kepada relasi interpersonal dikarenakan kemampuan kognitif anggota DPRD mengarahkan anggota DPRD menjadikan Pancasila sebagai orientasi kehidupan konstitusional. Perilaku anggota DPRD dalam bernegara tidak bisa lepas dan melenceng dari pemahaman terhadap Pancasila.

\section{DAFTAR PUSTAKA}

Alfaruqy, Z. (2016). Relasi interpersonal anggota dewan perwakilan rakyat daerah (Tesis tidak terpublikasi). UGM, Yogyakarta.

Alwi, A. (2017, Januari 2017). Kinerja DPRD Sumsel dinilai tidak efektif. Metro tv news. Retrieved from http://www.metrotvnews.com

Ashmore, R. D., Deaux, K., \& Mclaughlin-volpe, T. (2004). An organizing framework for collective identity: articulation and significance of multidimensionality. Psychological Bulletin, 130(1), 80-114. doi:10.1037/0033-2909.130.1.80

Balliet, D., Tybur, J. M., Wu, J., Antonellis, C., \& Lange, P. A. M. Van. (2016). Political ideology, trust, and cooperation : in-group favoritism among republicans and democrats during a us national election. Journal of Conflict Resolution, 1(22). doi $: 10.1177 / 0022002716658694$

Bappenas. (2015). Analisis pembangunan wilayah provinsi sumatera selatan. Jakarta: Badan Perencanaan Pembangunan Nasional.

Bennis, W., Manen V. J.,Schein. H. E.,\& Stelle,I. F (1979). Essays in interpersonal dynamics. Los Angles: The Dorsey Press

Bennis, W. (1983). Interpersonal dynamics. Los Angles: The Dorsey Press

Borland, E. (2014). Age dynamics and identity: conflict and cooperation among feminists in buenos aires, Research in Social Movements, Conflicts and Change Emerald Group Publishing Limited, 37, 83-106. doi:10.1108/S0163-786X20140000037003.

Buchan. R. N., Brewer. M. B., Grimalda. G., Wilson, Fata \& Foddy (2011). Global social identity and global cooperation. Psychological science 22(6) 821-828, doi: $10.1177 / 0956797611409590$

Deutsch, M. (2012). A theory of cooperation-competition and beyond. Dalam P. A. Van LangeA. W. Kruglanski \& E. T. A handbook of theories of social psychology, 2, 275-294. London: SAGE publications

Ellemers, N., \& Haslam, A. (2012). Social identity Theory. In V. Lange, Kruglanski, \& E. . Higgins (Eds.), Handbook of theories of social psychology, (2), 379-399. London: SAGE publications.

Eysenck, M. W., \& Keane, M. T. (2001). Cognitive Psychology 4th ed. Philadelphia: Taylor \& 
Francis Inc.

Faturochman. (2008). Model-model psikologi kebhinekatunggalikaan dan penerapannya di indonesia. Temu ilmiah Kongres Himapsi. Jurnal Psikologi Indonesia, 1, 1-15.

Fominiya. (2010). Collective identity in social movements: central concepts and debates. Sociology Compass 4(6), 393-404.

Kaelan. (2016). Pendidikan kewarganegaraan untuk perguruan tinggi. Yogyakarta: Paradigma press.

Natsir, F. N. (2010). Moral dan Etika Elite Politik. Yogyakarta: Pustaka Pelajar

Sameela, T. (2012). Intergroup relations among the ethiopian youth effects of ethnicity, language, and religious background. Journal of Developing Societies, 28(3), 323 - 354 ..

Sugiarti, E. (2010). Antara eksistensi dan lunturnya identitas colonial: orang ambon di Surabaya 1940-1950 an dalam kumpulan makalah kemerdekaan dan perubahan jati diri. Post-colonial indonesian identity, Yogyakarta.

Suhanda,E. (2002). Peran tipe-tipe relasi interpersonal pada perpaduan kelompok, produktivitas dan kepuasan anggota kelompok: Studi Terhadap Kelompok Swadaya Masyarakat Di Bandung (Tesis tidak terpublikasi). UGM, Yogyakarta.

Suseno, M.F.(2011). Nilai-nilai Pancasila sebagai orientasi pembudayaan kehidupan berkonstitusi. dalam Implementasi nilai-nilai Pancasila dalam menegakkan konstitusional Indonesia. Mahkamah konstitusi RI dengan Univeristas Gadjah Mada. Yogyakarta.

Steele, F. I., (1979). The instrumental relationship. Dalam Bennis, W., Manen V. J.,Schein. H. E.,\& Stelle,I. F (1979). Essays in interpersonal dynamics. Los Angles: The Dorsey Press.

Thibaut, J. W., Kelley, H. H. \& Homans, G.C.(2012). The social Exchange Theory. NY: John Wiley \& Sons.

Turner, J. \& Reynolds, K. (2012). Self-categorization theory. Dalam P. A. Van Lange A. W. Kruglanski \& E. T. Higgins Handbook of theories of social psychology, 2, 399-417. London: SAGE Publications Ltd.

Yuniarti, K. W. (2015). Meningkatkan kualitas pendidikan masyarakat melalui revolusi mental guna memperkuat identitas sosial budaya dalam rangka ketahanan nasional. Jakarta : Lemhanas. 